\title{
FINANCIAL CONDITIONS AND TRANSPARENCY OF THE CZECH PROFESSIONAL FOOTBALL CLUBS
}

\author{
David Procházka*
}

\begin{abstract}
:
The UEFA approved the Club Licensing and Financial Fair Play Regulation in 2010, which governs the requirements on transparency and financial conditions of football clubs participating at the European cups. The paper focuses on the specifics of Czech professional football clubs. The research is carried out in two ways. Firstly, the compliance with information duties set up by Czech commercial law is analysed. According to the performed empirical survey, a significant number of Czech football clubs submit their financial statements to the Business Register with a delay or they do not submit the statements at all despite the submission is mandatory. This unsatisfactory state of affairs boosts the risk of bankruptcy of football clubs rapidly taking into account an overall poor financial health of Czech football clubs, which is evidenced by the second part of empirical study.

Keywords: information duty, transparency of financial reporting, financial health, Czech professional football clubs, UEFA's Financial Fair Play.
\end{abstract}

JEL Classification: L83, M41, M21, G30

\section{Introduction}

On 27 May 2010, the Union of European Football Associations (UEFA) approved a new Club Licensing and Financial Fair Play Regulation (further only "Regulation") for the participation of football clubs in the UEFA competitions. Together with sporting criteria, the Regulation contains several important requirements on financial position and performance of the clubs. The UEFA is developing a new system of club licensing criteria, because a sport success of many clubs has been counteracted by a poor economic conditions and rising indebtedness. The long-standing financing hazard impairs a long-term survival of the football competitions; and penalises the clubs handling their financial matters with an appropriate care, too.

New requirements on financial health aim to improve the long-term financial sustainability of European club-scene by moving the attention from the short-run speculative trading and one-time spending to the long-term oriented activities and investments within a sound economic environment, where clubs do not operate with persistent losses and settle their liabilities on a timely basis. Should a football club not

* David Procházka, Department of Financial Accounting and Auditing, University of Economics, Prague (prochazd@vse.cz). The paper was processed under "Institutional Support of the Faculty of Finance and Accounting, University of Economics, Prague”. 
meet the criteria, it is not granted by a license, which allows the club to participate in the UEFA competitions. As the Champions League and the European League are competitions bringing great economic benefits to participating clubs, a failure in meeting the licensing requirements can cause severe losses to a "guilty" club. The compliance with provisions of regulation should prevent clubs from irresponsible economic behaviour, which threatens the interests of all stakeholders (such as players, creditors, municipalities, spectators, etc.), not only the UEFA's ones.

As the adoption of the Regulation has been supported by the evidence from all clubs associated under the UEFA's member countries (with a greater influence of top leagues), national specifics may have been omitted and the level of detail may have been too low to arrive at more founded conclusions. To provide a deeper insight into some issues relating to financial condition of football clubs, the paper focuses on the financial health of Czech professional football clubs. There are two main areas of interest. Firstly, the level of informativeness (i.e. the fulfilment of information duty) will be under suspicion. The financial reporting on a timely basis and in a sufficient manner is a crucial tool of input information for the evaluation of risk in doing business with football clubs. Secondly, a comprehensive analysis of financial health of all Czech professional football clubs is performed.

\section{Background and literature overview}

In the last decades, the importance of sport has been steadily increasing both in social and economic terms. Independently on the amateur level, the professional sport has become a stable part in profit-oriented economic structures. The key factor for economic success is a tight identification of fans with a particular sport club and/or an athlete. In the first instance, high-quality sport products bring benefits directly from the fans in a form of day-match revenues and souvenirs. Sponsorship, advertisement or broadcasting rights fees are examples of other significant sources of revenues. On the other side, sport events and competitions are often connected with adverse or even illegal behaviour such as betting, money laundering, corruption, etc. (FATF, 2009).

Professional sport and its economics is a subject of research for more than 60 years. The scope of research is very wide and includes such topics as league structures, team objectives, salaries, financing, broadcasting rights, performance, etc. A detailed analysis of the most important research areas was performed by Avgerinou (2007). Researchers put their focus especially on American professional leagues and European football. The first major work comes from Rottenberg (1956), who analysed economic consequences of players' reserve clause in the U.S. baseball leagues. A more general view on economics of sport was worked out by Neale (1964), who dealt with the desirability of competitive balance from the point of view of the profitability of sports teams. Economically, professional sport can be considered as a joint production, when a league's supervising body regulates schedules of matches, players' transfers, salaries, etc. A single club cannot satisfy the entirely market demand on its own. Rather than 
separate clubs, a whole league should be conceived as an economic firm, where each club has a similar position as the subsidiary of a particular economic group, for which decisions are taken and implemented collectively at the league level. Professional sport leagues possess similar economic attributes as cartel structures (Filinger, 2008, pp. 8-9). Because of supply and demand features of sport industry, which are favourable for the creation of natural monopoly, only one professional league usually exists on a certain market (Neale, 164, p. 14). It implies that government action may need to be undertaken in cases when the organisation of professional league violates public benefit in apparently anti-competitive modes (Dobson \& Goddard, 2001) or when legal system applicable on a given territory is broken.

Sloane (1971, p. 128) challenges the Neale's argument about a joint product. To analyse an entire league as a firm is not sufficient, as clubs are always independent economic subjects. However, profit is no more believed to be the sole motive for operating the business in football industry. Based on empirical study of English football clubs, Sloane broadens the scope of professional clubs objectives. Referring to economic theories on non-profit maximising firms (Machlup, 1967), Sloane proposes to focus on a multifactor utility function containing playing success, attendance, revenue, profit, survival, etc. rather than on profits only. This utility function, which links up a sport success of a professional sport club with its economic constraints, enables to clarify significant differences among various professional leagues and among various clubs within the same league. For example, restrictions imposed on salaries may lead to a relatively even dispersion of talented players between rich and poor clubs. Despite the fact that rich clubs has available funds for contracting the best players and thus to increase the chance to win league title, they are curtailed in such an activity because of salary capping. Persistent sporting hegemony of few clubs is then not probable (case of American professional leagues). Contrariwise, the European football scene is characterised by the non-existence of restriction on salaries. Therefore, huge differences exist between leagues and clubs, regarding both economic strength and sporting results. The sporting success of the top English, Spanish, German, Italian and few clubs from other countries in the UEFA Champions League and European Leagues is conditioned by their superior economic power.

The economic importance of European football is evidenced by the UEFA studies, according to which the aggregate reported income of European top division clubs is $€ 11.7$ billion (UEFA, 2011) and the aggregate amount of their bank debts and commercial loans are $€ 5.6$ billion, both figures for the season 2009/2010. A number of studies try to reveal causalities among different aspects of football business and sporting success. On the top of list is the relation between sport and economic performance. Szymanski \& Kuypers (1999) analysed the mutual dependency between sport performance and income in the English league, Murphy (1999) did a similar analysis for the Scottish league, Barajas et al. (2005) concentrated on the first and second Spanish division. A more sophisticated approach was adopted by Barros et al. (2008), who attempted to classify the Spanish football clubs into various segments based on different relationships among multiple sport and economic variables. 
The development of economic results in time and the overall financial situation of football clubs are relatively understated research issues. The main reason could be the restricted availability of needed data. An issue, this study will be focusing on, too. Some kind of evidence is available mainly for the five European top leagues, i.e. English (Buraimo et al., 2006), Italian (Baroncelli \& Lago, 2006), Spanish (Ascari \& Gagnepain, 2006; Boscá et al., 2008), German (Frick \& Prinz, 2006) and French (Gouguet \& Primault, 2006; Andreff, 2007). There is also some minor evidence for other leagues, such as in Belgium (Dejonghe \& Vandeweghe, 2006), Denmark (Storm, 2010), Greece (Panagiotis, 2009; Dimitropoulos, 2010), Portugal (Barros, 2006) or Scotland (Morrow, 2006a).

\section{Research design}

The above-mentioned studies revealed a relatively poor condition of football clubs across the Europe. Except for Germany, all leagues report substantial losses, high indebtedness and a permanently overall weak performance. The findings of the studies have two important consequences. On the theoretical level, there rise doubts about the effectiveness of collective league decision-making and empirically supports the Sloane's counterargument in favour of Neale's reasoning on the nature of professional sport leagues. On the practical level, an economic survival of some clubs or even leagues may be endangered, especially in a contemporary turbulent economic situation. The unsatisfactory financial situation of European football clubs was one of the chief reasons, why the UEFA approved the Regulation.

In the field of clubs' financial health, the Regulation (UEFA, 2010) aims at achieving the "financial fair play". There are two major ways how to achieve the financial fair play - football clubs are expected to be transparent and in satisfactory financial condition. The Regulation contains both short-term and long-term goals. As licenses have to be renewed for each season, clubs may be impelled by short run incentives just to meet the requirements for the actual season. This could have disastrous consequences to a long-term sustainability. The UEFA is well aware of this issue; therefore, some provisions on future financial information were incorporated in the Regulation. Any applicant must prepare and submit future financial information in order to demonstrate to ability to continue as a going concern until the end of the licence season.

The licensing of football clubs has been used by the UEFA since the season 2004/5005. A more comprehensive set of requirements will be put in force from the season 2012/2013. The Regulation is to ensure an equal approach for both economically responsible and irresponsible clubs, when the latter will not be allowed to "buy" a one-time success in an exchange for long-term financial problems. This target can be considered as an internal one, applicable for the purpose of the organisation of professional football competitions around Europe solely. However, the representatives of UEFA strive for a greater transparency of football business, too. In this context, the proposed Regulation can be helpful for all creditors, state authorities, football fans, 
sponsors and other stakeholders in meeting their information needs and assuring the credibility of football environment.

\subsection{Motivation for the paper and research hypotheses}

The transparency and timeliness in publishing financial statements is a key point, when assessing the financial position and performance. Financial statements are usually a primal source of financial information for the economic decision-making. Information from financial statements can be used by a wide range of users. Through the requirements on qualifying criteria set up by the UEFA, football clubs are forced to provide not only the regulator (i.e. the UEFA), but also other stakeholders with information that is more useful. The paper focuses therefore on two chief hypotheses:

- Is the financial reporting of Czech professional football clubs transparent?

- What is the overall financial situation of Czech professional football clubs?

The UEFA Regulation is relevant for all clubs playing in the member associations; however, the scope of this paper is limited to the Czech professional football clubs exclusively. There are several reasons for this specification. Firstly, Czech clubs create only insignificant part of European football market. ${ }^{1}$ Substantially different structures of operations and ways of their financing are used in comparison with the richer leagues (see figure at UEFA, 2011, p. 68). The local specifics may be then different from a general situation and the restriction set by the Regulation may turn to be ineffective and even prohibitive in some countries. Secondly, the recent change in format of the Champions League has increased the chance of qualifying in the group stage for clubs from "developing football countries" such as the Czech Republic is on a club level. The participation in the group stage provides the clubs with an opportunity to acquire a significant additional source of money, which may offer incentives to undertaken risky behaviour beyond the economic constraints available for a given club. On the level of individual clubs, such behaviour can be harmful "only" for the creditors of a particular club. However, if more financially irresponsible clubs within a league try to get a place in the qualifying rounds by finishing at the top of the league, their poor economic performance can negatively endanger the interests of remaining clubs. Thirdly, some Czech professional football clubs have experienced problems with an economic survival. The difficulties had hit even the traditional participants and recent winners of the Czech top league. The paper scrutinises whether these problems are only specific to a limited number of clubs or whether it is a general status quo of the Czech football club-scene.

1 The Czech league ranks 24 out of 53 leagues associated under the UEFA structure based on the revenue criterion. According to the UEFA (2011, p. 64) data, amount of revenue for an average club playing top league is $€ 16$ million. An average for the Czech first league is less than $€ 3$ million only. 
The paper contributes to the research in following ways:

- Firstly, the paper links the economics of sport with the transparency of financial reporting and tries to evaluate the impact of possible non-transparency on the users of financial statements.

- Secondly, the paper assesses the level of informativeness and fulfilment of information duty by an entire industry within a particular national economy.

- Thirdly, an analysis of financial health is performed, using complex models for the evaluation of financial situation. Such kind of analysis has been already done only for the "developed countries on the club level"; the case of Czech football clubs is the first attempt to analyse the situation in a relatively economically weak football league.

\subsection{Methodology and data description}

The research sample consists of 36 football clubs, which played the first and/or second football league at least for one of five football seasons covering periods from 2005/2006 until 2009/2010. A five-year period was chosen in order to obtain better evidence on trends. The first and the second league are professional competitions; each club has to apply for a professional licence granted by the Football Association of the Czech Republic to be allowed for the participation. The licence sets many prerequisites; e.g. legal status of football club. Only a business company established pursuant to Czech Commercial Code is allowed. Therefore, professional clubs have to comply with all legal requirements on enterprises, including financial reporting.

Professional clubs have to keep their accounts in conformity with the Czech accounting legislation governing the accounting and financial reporting of business entities. The annual financial statements have to be submitted to the Business Register, in which all information is publicly available. This fact enables to perform the research in the following way. The transparency can be evaluated by checking whether football clubs meet their information duties. The non-compliance ${ }^{2}$ with general law requirements applicable for all enterprises can be considered as a proxy measure assessing the transparency. Missing financial statements are an indicator of the increased risk for providers of capital as they lose an access to an independent source of financial information.

Furthermore, data will be extracted from financial statements submitted to the Business Register in order to evaluate overall financial position and performance of Czech professional football clubs. Financial figures may help to reveal the specifics influencing the financial health of football clubs. Thus, we may evaluate whether the economic situation of Czech football clubs concords to the generally accepted financial restrictions. For this type of research, all necessary data are usually extracted from the

2 The non-compliance means a delayed submission of financial statements or a failure to submit them at all. 
reputable databases. Eventually it turned out that the data for this particular study must have been obtained manually directly from the submitted financial statements. The first reason is that commercial databases contain information about some few selected companies solely. ${ }^{3}$ The second and main reason is that the clubs have different accounting policies (especially in the area of revenues ${ }^{4}$ and players' contracts). Careful investigation and manual adjustments of reported figures were inevitable to get comparable data.

\section{Results}

\subsection{Transparency of financial information}

Theoretically, 180 sets of financial statements should be available ( 5 seasons times 36 clubs). However, the sample comprises 97 sets only, ${ }^{5}$ which makes difference of 83 missing sets, as 73 clubs do not fulfil their information duty; eight clubs became business entities later than in the season 2005/2006; and two clubs changed the accounting period from a calendar to a fiscal year. Out of 36 clubs, only nine clubs have submitted financial reports in all five years under scrutiny; eighteen clubs fulfilled their information duty partly; and nine clubs did not post any set of financial statements. An average rate of submission of financial statements oscillates around $60 \% .^{6}$ The rate is relatively low, presuming that submission of financial statements is mandatory for all business entities operating in the Czech Republic and the non-compliance is supposed to be fined pursuant to Act on accounting. However, the findings of this study are similar to a more extensive research carried out by Tomis (2007, p. 48), who found out that only 53\% of Czech share companies had complied with requirements on submissions during years 2003-2005. Similar evidence on non-fulfilment of information duty in the football environment can be found in Barajas et al. (2005, p. 5) in case of Spanish clubs.

3 For example, the Amadeus database contains information about six clubs only.

4 Some clubs report the subsidies from municipalities and other public sector authorities as a part of their revenues from the chief operating activities; other clubs prefer disclosing these figures under other revenues or gains. For the purpose of this paper, all public subsidies were including in a figure capturing the revenue from chief operating activities.

5 The financial statements submitted to the Business Register by 1 July 2011 were taken into account only.

6 The exception is the season 2009/2010, for which the submission rate is considerably lower due to a relatively short time span from the end of reporting period. It could be expected that more financial statements will be submitted and the submission rate will increase (and average length of submission in days will prolong). However, none of additional submission will pass "hard criterion". 
Table 1

The Rate and Delay of Submission of Financial Statements to the Business Register

\begin{tabular}{|c|c|c|c|c|c|}
\hline & $2005 / 2006$ & $2006 / 2007$ & $2007 / 2008$ & $2008 / 2009$ & $2009 / 2010$ \\
\hline $\begin{array}{l}\text { Maximum number of financial } \\
\text { statements }\end{array}$ & 29 & 34 & 35 & 36 & 36 \\
\hline Number of non-submissions & 9 & 12 & 12 & 15 & 25 \\
\hline $\begin{array}{l}\text { Number of submitted financial } \\
\text { statements }\end{array}$ & 20 & 22 & 23 & 21 & 11 \\
\hline Submitted financial statements in \% & $69 \%$ & $65 \%$ & $66 \%$ & $58 \%$ & $31 \%$ \\
\hline Average length of submission (in days) & 447 & 453 & 296 & 245 & 181 \\
\hline $\begin{array}{l}\text { Number of late submissions - } \\
\text { soft criterion }\end{array}$ & 5 & 9 & 7 & 4 & 0 \\
\hline $\begin{array}{l}\text { Number of late submissions - } \\
\text { hard criterion }\end{array}$ & 15 & 17 & 14 & 10 & 5 \\
\hline
\end{tabular}

Source: authorial survey

Timeliness of financial statements submission can be assessed easily, as all documents submitted to the Register are marked with a submission date. Two criteria measuring the delay in submission of financial statements are used in this study:

- Soft criterion refers to Act on accounting, pursuant to which entities shall publish their financial statements within 30 days after being approved by the management, but not later than 12 months after the end of accounting period. Financial statements submitted later than 12 months after the corresponding period are then considered as deposited with a delay.

- Hard criterion refers to $\$ 184 a$ of Commercial Code, which requires all share companies to hold the General Meeting at least once a year, but not later than 6 months after the end of previous accounting period. Financial statements and annual reports are subject of an approval by shareholders at the General Meeting. Financial statements submitted later than 6 months after the period are then supposed to be submitted with a delay.

A major part of football clubs fulfils their information duty with some kind of delay or they do not fulfil it at all (Table 1). ${ }^{7}$ The level and timeliness of mandatory disclosure is therefore considerably low, which damages the transparency of football business. All parties interested in doing business with entities not fulfilling their informational duties have to obtain financial information in other way, which elicits additional costs.

7 In season 2005/2006, only 5 out of 29 clubs submitted their financial statements on time. Similarly only 5 clubs of 34 in season 2006/2007; 9 clubs out of 35 in season 2007/2008; 11 clubs out of 36 in season 2008/2009 and 6 out 36 clubs in season 2009/2010 submitted their financial statements within required time framework without breaching any rules. All other clubs violated the legal requirements at least at some extent. The non-compliance in area of financial reporting (as defined in the Footnote 2) is thus an inherent feature of Czech football environment. 
Creditors are unable to assess the financial health of a company from independent and reliable resources and they may be exposed to a higher risk, as far as repayment of their receivables concerns. To evaluate the extent of possible negative economic impacts on creditors and other stakeholders stemming from the situation when sport clubs do not fulfil their information duty, a more robust analysis of financial health of sport clubs needs to be performed.

\subsection{Financial situation}

\subsubsection{Descriptive statistics}

Data from financial statements submitted to the Business Register are generally used for the assessment of financial health. As mentioned above, 97 sets of financial statements of Czech professional football clubs were delivered to the Register over period 2005-2010. Totally 103 annual data sets were extracted from submitted statements. ${ }^{8}$ All data sets are subdivided into two groups according to the sort of accounting period used by entities.

Table 2

\section{Distribution of Financial Statements According to Accounting Period}

\begin{tabular}{|l|c|c|c|}
\hline Season & Calendar year & Fiscal year & Total \\
\hline $\mathbf{2 0 0 6}$ & 14 & 9 & 23 \\
\hline $\mathbf{2 0 0 7}$ & 13 & 11 & 24 \\
\hline $\mathbf{2 0 0 8}$ & 13 & 11 & 24 \\
\hline $\mathbf{2 0 0 9}$ & 10 & 11 & 21 \\
\hline $\mathbf{2 0 1 0}$ & 4 & 7 & 11 \\
\hline Total & 54 & 49 & 103 \\
\hline
\end{tabular}

Source: authorial survey; amounts are expressed in thousands CZK

Football clubs preferred the calendar year as a reporting basis in 54 cases. Alternatively, 49 sets of financial statements were prepared using the fiscal year (Table 2). For the purpose of this survey, each set of financial statements consists of information on nine financial variables.

Descriptive statistics in Table 3 reveal the initial inferences regarding the profitability and indebtedness. In six of ten subgroups, an average for earnings before interests and taxation is negative, which signals possible problems with profitability. The annual EBIT of an average club reached amount of CZK - 4,952 thousand over analysed five-year period..$^{9}$ In addition, the average equity is lower than subscribed capital in all ten subgroups. It means that on average, capital is eroded due to permanent losses.

8 In six cases, data for comparative periods were used instead of some missing sets of financial statements.

9 The median is also negative and reaches amount of CZK - 1,930 thousands. 
Table 3

Selected Information from Financial Statements - Descriptive Statistics

\begin{tabular}{|l|r|r|r|r|r|r|r|r|}
\hline & \multicolumn{2}{|c|}{ Maximum } & \multicolumn{2}{c|}{ Minimum } & \multicolumn{2}{c|}{ Average } & \multicolumn{2}{c|}{ Standard deviation } \\
\hline Period 2006 & Calendar & Fiscal & Calendar & Fiscal & Calendar & Fiscal & Calendar & Fiscal \\
\hline Total assets & 211,804 & 600,203 & 2,227 & 7,756 & 51,048 & 137,017 & 69,001 & 192,192 \\
\hline Current assets & 63,304 & 144,322 & 767 & 5,689 & 16,873 & 42,751 & 21,217 & 45,787 \\
\hline Equity & 148,680 & 164,643 & $-51,953$ & $-154,861$ & 12,986 & 20,434 & 45,389 & 96,063 \\
\hline Subscribed capital & 133,440 & 422,476 & 620 & 1,000 & 24,853 & 104,716 & 44,583 & 152,214 \\
\hline Total liabilities & 133,844 & 507,738 & 790 & 7,527 & 38,062 & 116,583 & 39,565 & 166,550 \\
\hline Current liabilities & 76,405 & 97,159 & 790 & 3,373 & 24,029 & 42,560 & 25,446 & 36,069 \\
\hline Revenue & 158,210 & 625,118 & 1,405 & 36,399 & 48,986 & 139,552 & 45,786 & 187,104 \\
\hline Interest expense & 2,122 & 17,492 & 0 & 0 & 495 & 3,069 & 661 & 5,724 \\
\hline EBIT & 21,212 & 32,521 & $-12,397$ & $-54,168$ & 13 & $-12,454$ & 7,733 & 25,326 \\
\hline
\end{tabular}

\begin{tabular}{|l|c|c|c|r|r|r|r|c|}
\hline & \multicolumn{2}{|c|}{ Maximum } & \multicolumn{2}{c|}{ Minimum } & \multicolumn{2}{c|}{ Average } & \multicolumn{2}{c|}{ Standard deviation } \\
\hline Period 2007 & Calendar & Fiscal & Calendar & Fiscal & Calendar & Fiscal & Calendar & Fiscal \\
\hline Total assets & 257,928 & 668,046 & 3,345 & 7,104 & 67,392 & 123,526 & 85,197 & 198,179 \\
\hline Current assets & 122,804 & 229,188 & 1,148 & 1,008 & 23,799 & 48,675 & 34,031 & 67,394 \\
\hline Equity & 166,865 & 158,436 & $-10,962$ & & 19,109 & 7,011 & 48,759 & 95,178 \\
\hline Subscribed capital & 198,705 & 422,476 & 620 & 2,000 & 31,973 & 87,495 & 61,541 & 141,466 \\
\hline Total liabilities & 208,377 & 625,578 & 4,058 & 4,712 & 48,283 & 116,515 & 61,262 & 189,161 \\
\hline Current liabilities & 102,919 & 104,172 & 1,771 & 3,062 & 27,324 & 37,659 & 32,834 & 40,157 \\
\hline Revenue & 223,055 & 469,111 & 5,583 & 23,781 & 65,684 & 105,145 & 69,803 & 125,749 \\
\hline Interest expense & 4,475 & 21,861 & 0 & 1 & 741 & 3,068 & 1,228 & 6,661 \\
\hline EBIT & 32,828 & 6,379 & $-22,083$ & $-53,288$ & 1,094 & $-10,042$ & 14,384 & 17,249 \\
\hline
\end{tabular}

\begin{tabular}{|l|r|r|r|r|r|r|r|r|}
\hline & \multicolumn{2}{|c|}{ Maximum } & \multicolumn{2}{c|}{ Minimum } & \multicolumn{2}{c|}{ Average } & \multicolumn{2}{c|}{ Standard deviation } \\
\hline Period 2008 & Calendar & \multicolumn{1}{|c|}{ Fiscal } & Calendar & Fiscal & Calendar & Fiscal & \multicolumn{1}{c|}{ Calendar } & Fiscal \\
\hline Total assets & 286,724 & 857,626 & 799 & 8,290 & 73,008 & 182,362 & 91,912 & 279,974 \\
\hline Current assets & 106,789 & 159,492 & 271 & 4,084 & 23,073 & 45,660 & 29,180 & 49,118 \\
\hline Equity & 187,481 & 640,358 & $-15,491$ & $-20,966$ & 29,934 & 79,918 & 58,501 & 192,845 \\
\hline Subscribed capital & 198,705 & $1,040,476$ & 620 & 2,000 & 35,334 & 148,131 & 62,543 & 317,765 \\
\hline Total liabilities & 234,914 & 596,024 & 636 & 4,209 & 43,074 & 102,444 & 61,862 & 176,226 \\
\hline Current liabilities & 70,053 & 128,222 & 324 & 3,781 & 19,722 & 40,388 & 20,455 & 46,967 \\
\hline Revenue & 261,153 & 464,621 & 1,349 & 30,228 & 85,313 & 141,077 & 84,919 & 165,614 \\
\hline Interest expense & 6,552 & 28,922 & 0 & 0 & 947 & 3,983 & 1,760 & 8,842 \\
\hline EBIT & 93,442 & 247,593 & $-20,297$ & $-127,165$ & 9,013 & 8,367 & 30,447 & 88,260 \\
\hline
\end{tabular}


Table 3 - Continuation

\begin{tabular}{|l|c|r|r|r|r|r|r|c|}
\hline & \multicolumn{2}{|c|}{ Maximum } & \multicolumn{2}{c|}{ Minimum } & \multicolumn{2}{c|}{ Average } & \multicolumn{2}{c|}{ Standard deviation } \\
\hline Period 2009 & Calendar & Fiscal & Calendar & Fiscal & Calendar & Fiscal & Calendar & Fiscal \\
\hline Total assets & 322,881 & 535,829 & 2,204 & 5,273 & 67,919 & 138,076 & 107,772 & 178,192 \\
\hline Current assets & 55,308 & 127,161 & 1,206 & 938 & 17,823 & 39,441 & 18,694 & 46,188 \\
\hline Equity & 182,620 & 288,138 & $-13,257$ & $-57,059$ & 20,619 & 43,153 & 59,285 & 105,115 \\
\hline Subscribed capital & 133,440 & 494,970 & 620 & 2,000 & 24,864 & 102,270 & 43,970 & 169,806 \\
\hline Total liabilities & 276,924 & 584,605 & 2,164 & 6,191 & 47,300 & 94,923 & 83,785 & 169,900 \\
\hline Current liabilities & 66,850 & 162,091 & 1,948 & 3,190 & 19,276 & 48,921 & 23,598 & 61,295 \\
\hline Revenue & 93,021 & 429,521 & 8,741 & 11,388 & 44,818 & 100,350 & 31,847 & 117,598 \\
\hline Interest expense & 4,668 & 28,465 & 4 & 0 & 832 & 3,110 & 1,430 & 8,477 \\
\hline EBIT & 9,859 & 16,217 & $-18,104$ & $-123,339$ & $-2,634$ & $-19,020$ & 7,490 & 38,357 \\
\hline
\end{tabular}

\begin{tabular}{|l|r|r|r|r|r|r|c|c|}
\hline & \multicolumn{2}{|c|}{ Maximum } & \multicolumn{2}{c|}{ Minimum } & \multicolumn{2}{c|}{ Average } & \multicolumn{2}{c|}{ Standard deviation } \\
\hline Period 2010 & Calendar & Fiscal & Calendar & Fiscal & Calendar & Fiscal & Calendar & Fiscal \\
\hline Total assets & 207,223 & 516,547 & 3,176 & 16,369 & 64,622 & 218,519 & 96,763 & 191,880 \\
\hline Current assets & 36,915 & 94,361 & 1,308 & 6,586 & 18,485 & 51,288 & 19,216 & 29,089 \\
\hline Equity & 181,835 & 277,794 & 3 & $-167,977$ & 46,355 & 36,750 & 90,324 & 164,032 \\
\hline Subscribed capital & 142,440 & 610,170 & 620 & 2,000 & 40,365 & 171,510 & 68,423 & 232,385 \\
\hline Total liabilities & 41,202 & 679,389 & 3,173 & 4,998 & 18,267 & 181,768 & 18,515 & 231,230 \\
\hline Current liabilities & 22,751 & 297,050 & 2,177 & 3,561 & 12,425 & 119,499 & 11,405 & 106,546 \\
\hline Revenue & 85,330 & 311,480 & 13,302 & 36,025 & 52,019 & 107,431 & 36,671 & 93,657 \\
\hline Interest expense & 1,105 & 27,413 & 4 & 0 & 309 & 4,708 & 532 & 10,146 \\
\hline EBIT & 13,452 & 3,625 & $-15,754$ & $-157,992$ & -10 & $-39,356$ & 12,011 & 63,441 \\
\hline
\end{tabular}

Source: authorial calculations; amounts are expressed in thousands CZK

Fundamental data retrieved from financial statements imply that a long-term stability of Czech football clubs is broken down. Further economic survival is questionable, which increases a credit risk, because long-term losses reduce funds available for the pay-offs of liabilities. The best economic results were attained in year 2008 (season 2007/2008); the worst figures on performance occurred a year (season) later. The deterioration could have been strongly influenced by the recent economic crisis; however, the situation had been bad already before the crisis began.

\subsubsection{Analytical tests of performance and capital adequacy}

Descriptive statistics offers a preliminary view about the weak condition of Czech football clubs. As averages may be distorted by extreme values, additional analysis of financial health and capital stability is performed. Firstly, a total number of reported negative EBIT figures are counted for each year. In $61 \%$ of cases, clubs reported a negative amount of earnings before interests and taxation, which supports a previous conclusion about an overall bad financial performance. Although, the result is not favourable, it fully corresponds to the situation in the whole Europe. Although by 
coincidence, the UEFA (2011, p. 81) survey revealed that the same percentage (i.e. 61\%) of European top division clubs experienced operating losses in the season 2009/2010.

The importance of findings on the EBIT criterion is confirmed by two additional tests on capital adequacy of Czech football clubs. In order to achieve the results as objective as possible, tests are designed with reference to legally binding provisions of Commercial Code on capital adequacy. Pursuant to $\$ 193$, the managing board of a company, which accumulated losses exceed $50 \%$ of subscribed capital, is obliged to inform the General Meeting of shareholders, who shall undertake measures to improve the state of business affairs. According to Table 4, a failure in the Equity Test No. 1 is shown in 54 cases out of 103. More than half of football clubs have to solve drops in capital adequacy each year. However, the problem is usually ignored and solved insufficiently or even not solved at all, how it can be seen from the notes to financial statements. ${ }^{10}$

Table 4

Analytical Tests on Profitability and Capital Adequacy

\begin{tabular}{|c|c|c|c|c|c|}
\hline Season & Test & Calendar & Fiscal & Total cases & $\%$ \\
\hline \multirow{3}{*}{2006} & Negative EBIT & 8 & 7 & 15 & $65 \%$ \\
\hline & Equity Test No. 1 & 8 & 6 & 14 & $61 \%$ \\
\hline & Equity Test No. 2 & 6 & 3 & 9 & $39 \%$ \\
\hline \multirow{3}{*}{2007} & Negative EBIT & 8 & 7 & 15 & $63 \%$ \\
\hline & Equity Test No. 1 & 9 & 6 & 15 & $63 \%$ \\
\hline & Equity Test No. 2 & 6 & 4 & 10 & $42 \%$ \\
\hline \multirow{3}{*}{2008} & Negative EBIT & 6 & 6 & 12 & $50 \%$ \\
\hline & Equity Test No. 1 & 8 & 3 & 11 & $46 \%$ \\
\hline & Equity Test No. 2 & 4 & 3 & 7 & $29 \%$ \\
\hline \multirow{3}{*}{2009} & Negative EBIT & 7 & 8 & 15 & $71 \%$ \\
\hline & Equity Test No. 1 & 6 & 4 & 10 & $48 \%$ \\
\hline & Equity Test No. 2 & 4 & 4 & 8 & $38 \%$ \\
\hline \multirow{3}{*}{2010} & Negative EBIT & 1 & 5 & 6 & $55 \%$ \\
\hline & Equity Test No. 1 & 2 & 2 & 4 & $36 \%$ \\
\hline & Equity Test No. 2 & 0 & 2 & 2 & $18 \%$ \\
\hline \multicolumn{2}{|c|}{ Negative EBIT - total count } & 30 & 33 & 63 & $61 \%$ \\
\hline \multicolumn{2}{|c|}{ Equity test No. $1-$ total count } & 33 & 21 & 54 & $52 \%$ \\
\hline \multicolumn{2}{|c|}{ Equity test No. 2 - total count } & 20 & 16 & 36 & $35 \%$ \\
\hline
\end{tabular}

Source: authorial calculations

Furthermore, $\S 193$ of Commercial Code establishes a duty to call the General Meeting provided that results of business operations indicate the default of a company. A company is in the default, if it has more creditors, its liabilities are more than 30 days

10 Auditors ignore this important legal condition in their opinions, too. 
after due date, and it is unable to settle its liabilities ( $\$ 3$ of Insolvency Act). The actual symptoms of a default as defined by Insolvency Act are known only to managers; therefore, it is impossible for the outsiders to detect directly, whether a company has defaulted or not. However, some kind of information from financial statements can be utilised, so that creditors can obtain a proxy measure of potential default of clubs as their trading partners.

It is presumed that a football club has defaulted, if two conditions are met simultaneously. Firstly, a football club reports negative equity (which substitutes a condition that a company is unable to settle its liabilities). Secondly, the club discloses information on liabilities over their maturity. In 36 of 103 observations, the negative equity is reported. Furthermore, information on liabilities opened after due date is present in 78 cases; and only in 16 cases entities have no due, but unpaid liabilities. Remaining 62 observations contain due and unpaid liabilities. All 36 cases with negative equity are accompanied with liabilities passing their maturity. As a result, $35 \%$ of Czech professional football clubs can be denoted as operating permanently in a default position, which may turn into bankruptcy. The results of Equity Test No. 2 are similar to the findings of the UEFA (2011, p. 17), which found that 37\% of top division clubs reported the negative equity. However, the percentage for Czech clubs may be higher, as we do not have data on all clubs (including two, which went bankrupted actually).

\subsubsection{Financial health}

The previous conclusion about a high risk of bankruptcy is based on a relatively simple criterion of negative equity and liabilities after maturity as defined by Czech law. Moreover, the results of Equity Test No. 2 are limited by missing information on liabilities after due date in financial statements. Therefore, for the evaluation of financial health, a complex model for detecting the risk of default/bankruptcy is used. Altman's (1968) Z-Score is probably the most famous type of such a predictive model. Its chief disadvantage impeding the application in this study is that the factors, coefficients and weights are derived from the data on U.S. companies. The Index INO5 (Neumaier \& Neumaierová, 2005), calibrated for the Czech business environment, is applied instead. The model's specification is as follows:

$$
\mathrm{IN} 05=0.13 * \frac{T A}{T L}+0.04 * \frac{E B I T}{I}+3.97 \frac{E B I T}{T A}+0.21 * \frac{R E V}{T A}+0.09 * \frac{C A}{C L}
$$

where $T A-$ total assets,

$T L \quad$ - total liabilities,

$E B I T$ - earnings before interest and taxation,

$I \quad$ - interest expenses,

$R E V$ - revenue,

$C A$ - current assets,

$C L$ - current liabilities. 
Index INO5 is a combined predictive model integrating information on both the default probability and the creation of value. The Index INO5 is the last version of a model, which has been developing since 1990's, and its critical values are following:

- IN05 < 0.9: $97 \%$ probability of bankruptcy and $24 \%$ probability of value creation (so called "bankruptcy zone");

- $\quad 0.9<I N 05<1.6$ : $50 \%$ probability of bankruptcy and $24 \%$ probability of value creation (so called "grey zone");

- IN05>1.6: $8 \%$ probability of bankruptcy and $95 \%$ probability of value creation (so called "prosperity zone").

Financial figures (Table 3) were used for the calculation of Index IN05 for each club and for each accounting period, where data are available (i.e. 103 observations in total). A model evaluating financial health complexly (Table 5) confirms the previous findings on a poor economic condition of the Czech professional football clubs. According to the results of analysis performed under $I N O 5^{11}$ model, almost $60 \%$ of observations fall into the "bankruptcy zone". Moreover, the value of IN05 was negative in 37 cases. $17 \%$ of football clubs belongs to "grey zone", i.e. the model cannot decide to which way a company will go. Finally, only one quarter of the clubs flourish, and the risks of insolvency or bankruptcy are negligible.

The comprehensive study using a model predicting financial distress reveals that only $25 \%$ of clubs are in an acceptable economic shape concerning their future prospects. Almost two thirds of clubs reported negative earnings; one third of them had negative equity. This clubs are in or very close to a state of virtual bankruptcy (see last row in Table 5). Such a state of affairs boosts rapidly the risk of making business with football clubs. To make things even worse, the findings on non-compliance with information duties shall be recalled. The rate of submission of financial statements into the Business Register by Czech football clubs is only about $60 \%$. Czech professional football clubs are generally in a very poor financial situation. Moreover, it is difficult to determine faithfully how bad their financial health is, because clubs do not present financial statements properly. Consequently, capital providers may lose their money as significant risk of default and/or bankruptcy exists. This scenario is not only hypothetical. Over analysed five seasons, three clubs became bankrupted. It is symptomatic, indeed, that two of those three clubs did not fulfil their information duty at all.

11 According to the recommendation of model's authors (Neumaier \& Neumaierová, 2005, p. 147), the value of criterion EBIT/I was restricted to 9 (and - 9 respectively) to avoid the distortion of results due to values of interest expenses near to zero. 
Table 5

Index IN05 - Predictive Model of Financial Health

\begin{tabular}{|c|c|c|c|c|c|}
\hline Period & Index IN05 & Calendar & Fiscal & Total cases & $\%$ \\
\hline \multirow{3}{*}{2006} & IN05>1.6 & 6 & 1 & 7 & $30 \%$ \\
\hline & $0.9<\mathrm{IN} 05<1.6$ & 0 & 2 & 2 & $9 \%$ \\
\hline & IN05<0.9 & 8 & 6 & 14 & $61 \%$ \\
\hline \multirow{3}{*}{2007} & IN05>1.6 & 3 & 3 & 6 & $25 \%$ \\
\hline & $0.9<\mathrm{IN} 05<1.6$ & 1 & 1 & 2 & $8 \%$ \\
\hline & IN05<0.9 & 9 & 7 & 16 & $67 \%$ \\
\hline \multirow{3}{*}{2008} & IN05>1.6 & 5 & 2 & 7 & $29 \%$ \\
\hline & $0.9<\mathrm{IN} 05<1.6$ & 2 & 5 & 7 & $29 \%$ \\
\hline & IN05<0.9 & 6 & 4 & 10 & $42 \%$ \\
\hline \multirow{3}{*}{2009} & IN05>1.6 & 1 & 1 & 2 & $10 \%$ \\
\hline & $0.9<\mathrm{IN} 05<1.6$ & 4 & 2 & 6 & $29 \%$ \\
\hline & IN $05<0.9$ & 5 & 8 & 13 & $62 \%$ \\
\hline \multirow{3}{*}{2010} & IN05>1.6 & 3 & 1 & 4 & $36 \%$ \\
\hline & $0.9<$ IN $05<1.6$ & 0 & 0 & 0 & $0 \%$ \\
\hline & IN05<0.9 & 1 & 6 & 7 & $64 \%$ \\
\hline \multicolumn{2}{|c|}{ IN05>1.6 - total count } & 18 & 8 & 26 & $25 \%$ \\
\hline \multicolumn{2}{|c|}{$0.9<$ IN $05<1.6-$ total count } & 7 & 10 & 17 & $17 \%$ \\
\hline \multicolumn{2}{|c|}{ IN $05<0.9-$ total count } & 29 & 31 & 60 & $58 \%$ \\
\hline
\end{tabular}

Source: authorial calculations

\section{Conclusions}

Paper analyses the financial health of companies operating in a selected field of business. Namely, the focus was put on the Czech professional football clubs. An empirical study revealed several important features relating to the level of informativeness and financial health of football clubs playing the first and second league.

Firstly, the rate of submission of financial statements to the Business Register is rather low (about 60\%), despite the fact that delivery of financial statements to the Register is mandatory both according to Commercial Code and Act on Accounting. Secondly, majority of those clubs, which do submit their financials, does it with a considerable delay. In this context, it should be highlighted that a delayed submission or even missing financial statements are the main limitation of conclusions regarding the financial health of Czech football clubs.

Thirdly, Czech professional football suffers from a poor economic performance. Majority of clubs reports regularly losses. Annual loss before interests and taxation mounting up to almost CZK 5 million (which is about 5\% of total assets) is incurred 
by an "average" club each year. Equity is often negative and football clubs are unable to meet their liabilities on time. Consequently, one third of clubs appears virtually in a permanent default. In some cases, the virtual defaults turned to real ones; and other clubs have survived just on the edge. Even the clubs with a long tradition are not immune to economic problems.

All mentioned factors lead to a situation that Czech football scene represents a very risky environment for all parties, which do not have any other access to financial information than to those contained in financial statements. The decision whether to conclude any contract to deliver goods or service to Czech professional football clubs needs a higher alertness, with the impact on cost of capital provided by creditors. The financial health of football clubs is thus further worsened. Creditors may lose their money as significant risk of default and/or bankruptcy exists. Three clubs bankrupted during the five-year period covered by this study. To underline the extent of problem, it should be reminded that two of bankrupted clubs had not fulfilled their information duty at all.

The future research should address several topics. Firstly, a comparison with football clubs from other European countries should be performed to find out the similarities and differences in comparison with the Czech clubs. Regular studies published by the UEFA are useful in some extent, but they are limited in at least two directions. The UEFA informs on selected financial figures, but a complex assessment of financial health and its development in time, as presented in this study, is missing. Secondly, to ensure a long-term stability in the industry of professional football it is necessary to reveal all interconnected factors influencing the economic performance of clubs. The UEFA publishes some of such kind of information, but only for five biggest leagues (England, Spain, Germany, Italy, and France). Evidence for other countries respecting national specifics should be helpful in obtaining a more comprehensive view.

A more detailed analysis is also required to address the cardinal unclear issue arising from the findings of this preliminary survey. How is it possible that a relatively high number of Czech football clubs survives even though they conduct their business with long-term losses? Empirical survey shows that one third of Czech football clubs operates with a negative equity. A predictive model provides even worse results. Based on data from financial statements, two thirds of clubs indicate marks of financial distress with a high probability of bankruptcy. Despite these negative results, only three clubs of 36 analysed went actually bankrupted. How is this state of affairs, which is in contradiction with the fundamentals of economic theory, feasible? An answer could be that creditors are unwilling to prosecute the football clubs to meet their liabilities. Football is an important social phenomenon, and a judicial enforcement of receivables fulfilment can impose a negative impression on creditors. Therefore, they mitigate the conditions and terms, under which their receivables have to be paid by football clubs (compare with the Morrow's, 2006b) remark on the Lazio's Rome settlement of its huge tax liabilities). However, the empirical evidence of this conjecture has to be found yet. 
Previous study's limitations and suggestions about potential future research relate to the sphere of financial reporting and corporate governance in general. However, we can spot one issue relating to the general economic theory. The impacts of the UEFA Regulation shall be assessed not only in terms of the response of football clubs to its requirements. If the Regulation's bold goals regarding indebtedness and transparency of football clubs participating in the European cups are met in future, we can obtain some kind of evidence that external parties may benefit from the self-regulation of a certain industry. In this context, the analysis of differences between pre-adoption and post-adoption behaviour of football clubs can contribute to the research on economic regulation (Posner, 1974).

\section{References}

Altman, E. I. (1968), "Financial Ratios, Discriminant Analysis and the Prediction of Corporate Bankruptcy." Journal of Finance, Vol. 23, No. 4, pp. 589-609.

Andreff, W. (2007), "French Football: A Financial Crisis Rooted in Weak Governance." Journal of Sports Economics, Vol. 8, No. 6, pp. 652-61.

Ascari, G., Gagnepain, P. (2006), "Spanish Football." Journal of Sports Economics, Vol. 7, No. 1, pp. 76-89.

Avgerinou, V. (2007), "The Economics of Professional Team Sports: Content, Trends and Future Developments." Sport Management International Journal, Vol. 3, No. 1, pp. 5-17.

Barajas, A., Fernández-Jardón, C., Crolley, L. (2005), "Does Sports Performance Influence Revenues and Economic Results in Spanish Football?" MPRA Paper No. 3234, [online] http:// mpra.ub.uni-muenchen.de/3234/

Baroncelli, A., Lago, U. (2006), “Italian Football.” Journal of Sports Economics, Vol. 7, No. 1, pp. 13-28.

Barros, C. P. (2006), "Portuguese Football." Journal of Sports Economics, Vol. 7, No. 1, pp. 96-104.

Barros, C. P., del Corral, J., Garcia-del-Barrio, P. (2008), "Identification of Segments of Soccer Clubs in the Spanish League First Division with a Latent Class Model." Journal of Sports Economics, Vol. 9, No. 5, pp. 451-469.

Boscá, J. E., Liern, V., Martínez, A., Sala, R. (2008), "The Spanish Football Crisis." European Sport Management Quarterly, Vol. 8, No. 2, pp. 165-177.

Buraimo, B., Simmons, R., Szymanski, S. (2006), "English Football." Journal of Sports Economics, Vol. 7, No. 1, pp. 29-46.

Dejonghe, T., Vandeweghe, H. (2006), "Belgian Football." Journal of Sports Economics, Vol. 7, No. 1, pp. 105-113.

Dimitropoulos, P. (2010), "The Financial Performance of the Greek Football Clubs." Sport Management International Journal, Vol. 6, No. 1, pp. 5-27.

Dobson, S., Goddard, J. (2001), The Economics of Football. Cambridge: Cambridge University Press.

Filinger, J. (2008), “Účetní výkaznictví profesionálních sportovních klubů.” University of Economics, Prague: doctoral thesis.

Financial Action Task Force (2009), "Money Laundering through the Football Sector." Paris: FATF/ OECD.

Frick, B., Prinz, U. (2006), "Crisis? What Crisis? Football in Germany". Journal of Sports Economics, Vol. 7, No. 1, pp. 60-75. 
Gouguet, J. J., Primault, D. (2006), "The French Exception”. Journal of Sports Economics, Vol. 7, No. 1, pp. 47-59.

Machlup, F. (1967), "Theories of the Firm: Marginalist, Behavioral, Managerial". The American Economic Review, Vol. 57, No. 1, pp. 1-33.

Morrow, S. (2006a), "Scottish Football: It's a Funny Old Business." Journal of Sports Economics, Vol. 7, No. 1, pp. 90-95.

Morrow, S. (2006b), "Impression Management in Football Club Financial Reporting." International Journal of Sport Finance, Vol. 1, pp. 96-108.

Murphy, P. (1999), "For Richer, for Poorer North of the Border: Examining the Link between Resources and Performance in Scottish Elite Football." Singer \& Friedlander: Review 1998-99 Season, pp. $45-49$.

Neale, W. C. (1964), "The Peculiar Economics of Professional Sports." Quarterly Journal of Economics, pp. 1-14.

Neumaier, I., Neumaierová, I. (2005), "Index IN05." Brno, Evropské finanční systémy, June 21-23, 2005.

Panagiotis, D. E. (2009), "Profitability of the Greek Football Clubs: Implications for Financial Decision Making." Business Intelligence Journal, Vol. 2, No. 1, pp. 159-170.

Posner, R. A. (1974), “Theories of Economic Regulation." The Bell Journal of Economics and Management Science, Vol. 5, No. 2, pp. 335-358.

Rottenberg, S. (1956), “The Baseball Players' Labor Market.” Journal of Political Economy, pp. 242-258.

Sloane, P. J. (1971), "The Economics of Professional Football: The Football Club as a Utility Maximiser". Scottish Journal of Political Economy, pp. 121-146.

Storm, R. K. (2010), "Winners and Losers in Danish Football." Malmö, International Conference on Sports, April 8-12, 2010.

Szymanski, S., Kuypers, T. (1999), Winners and Losers: The Business Strategy of Football. Penguin: Harmondsworth.

Tomis, A. (2007), "PInění základních informačních povinností českým obchodními společnostmi." Charles University: Master Thesis.

Union of European Football Associations (2010), "UEFA Club Licensing and Financial Fair Play Regulations: Edition 2010." Nyon, UEFA.

Union of European Football Associations (2011), "The European Club Footballing Landscape: Club Licensing Benchmarking Report Financial Year 2009.” Nyon, UEFA. 